\title{
Constitutional aspects of the current reform of the selecting constitutional judges in the Slovak Republic and the comparative perspectives in Europe
}

PhD. Simona FARKAŠOVÁ

\begin{abstract}
This document concerns the issue of constitutional reform of the Slovak constitutional judiciary in 2021, which resulted in major changes of the composition, establishment, and powers of the Constitutional Court of the SR. While discussing the constitutional reform of the Constitutional Court, the author first of all points to the evolution of the selection of constitutional judges. This document summarizes new and precised criteria for the selection of constitutional judges and details how, according to constitutional requirements, competing candidates have to be assessed subsequently, provides an overview of the election procedure of the candidates for constitutional judges in parliament. The imminent part of this document is the comparative analysis of the issue of the constitutional judiciary, with special regard to the selection of constitutional judges in selected member states of the European Union, the synthesis of common features and subsequently the description of the proposal de constitutione ferenda. All of these used methods of scientific research led the author to formulate final conclusion whether the actual constitutional reform is able to fulfill its aim, which is to prevent the political power from interferenting with the independence and effective functioning of the constitutional judiciary.
\end{abstract}

Keywords: Constitutional judiciary, the Constitutional Court of the Slovak republic, constitutional reform, the model of selection the judges of Constitutional Court in Europe, independency of judicial power

JEL Classification: K19, K40

DOI: $10.24818 / \mathrm{TBJ} / 2021 / 11 / 2.02$

\section{Introduction}

Constitutional Courts are primarily adjudicative structures assigned the task of clarifying the constitution's meaning. They present themselves to citizens as bodies that render judgments in which a legal (and often political) dispute rests in part on how the constitution should be understood and applied. ${ }^{2}$ Constitutional Court can be defined as judicial-type bodies that, in a political system, have a monopoly on the assessment of the constitutionality of legislation and the power to invalidate

\footnotetext{
${ }^{1}$ Simona Farkašová - PhD., Faculty of Law, University of Pavol Jozef Safarik in Kosice, Slovakia, simona.farkasova@upjs.sk.

${ }^{2}$ Brown, N. J., Waller, J. G., Constitutional courts and political uncertainty: Constitutional ruptures and the rule of judges, "International Journal of Constitutional Law", 2016, Vol. 14, No. 4, p. 819.
} 
laws and statutes that do not conform to the constitution. ${ }^{3}$ Yet because they have such a role in the addressing fundamental questions, the protection of constitutionality only makes sense and serves its purpose if it is real, unpretentious, and effective. To be able to retain these qualities, it is necessary to select the judges that are professionally qualified with excellent legal knowledge and have high moral integrity with respect for fundamental rights to consistently protect the constitution in the most demanding matters. At the top of the properly functioning Constitutional Court, it is the judge independent in judgment. It allows judges to make impartial decisions in accordance with law and evidence, only, shielding from inappropriate outside influence, whether from other branches of government, the public, or the private sector. Independent judges are expected to be incorruptible and fearless; they should be able, where necessary, to decide cases in ways that may upset government, media, and public opinion. ${ }^{4}$

All of these qualities must necessarily come from a judge's ability to see things differently from elected politicians. If judges were similar to elected politicians, they would lose their distinctive function. ${ }^{5}$ There may seem to be a contrary - what if the aim of the relevant holders of political power is to select a judge who sees things the same, resp. similarly? In other words - what if the aim of the relevant holders of political power is to select the dependent members and not the independent constitutional experts?

Doubts about court independence and politicization of the judicial systems have been raised not only with respect to authoritarian regimes or captured democracies, but also with reference to countries that are commonly perceived as consolidated democracies and free. ${ }^{6}$ Although the term "politicization" is rather catchy, in need of some clarification; for example Rosa M. Navarrete, Pablo CastilloOrtiz define politicization as "the introduction or intensification of ideological or party-political logics in the design and process of decision-making of judicial institution." "Other authors, mainly from post-socialistic countries in Central and East Europe, develop a definition of politicization in the context with the constitutional judiciary by pointing out to the casual link between the deficit of political and legal culture with the absence of experience with the functioning of democratic mechanisms and inadequate and insufficient extent of judicial independence, which may bring the threat of politically loyal judges. For example A. Badó critically states that: "the democratic traditions and the frailness of the politico-legal culture provide a fertile ground for the creation of an opportunistic

\footnotetext{
${ }^{3}$ Castillo-Ortiz P., The dilemmas of constitutional courts and the case for a new design of Kelsenian institutions, "Law and Philosophy“", 2020, Vol. 39, p. 618.

${ }^{4}$ Dijk, F. V., Vos, G., A method for assessment of the independence and accountability of the Judiciary, ’International Journal for Court Administration”, 2018, Vol. 9, no. 3, p. 2.

${ }^{5}$ Vandamme, P. É., Hutt, D. B., Selecting Constitutional Judges Randomly, "Swiss political Science Review", 2021, p. 2.

6 Fałkowski, J., Lewkowicz, J., Are Adjudication Panels strategically selected? The case of Constitutional Court in Poland, "International Review of Law and Economics", 2021, Vol. 65, p. 1.

${ }^{7}$ Navarrete R. M., Castillo-Ortiz P., Constitutional courts and citizens' perceptions of judicial systems in Europe, "Comparative European Politics", 2020, Vol.18, no. 2, p.133.
} 
judiciary loyal to the government." 8 According to S. Spáč "Slovak judiciary is a typical example of a postcommunist bureaucratic judiciary, such that bureaucratic and corporatist attitudes may skew the process in favor of candidates who would pose the least threat to the status quo." ${ }^{\text {L }}$. Orosz claims that: "political elites are being fully aware, that one of the key tendencies in the development of recent democratic states is the general strengthening of the judicial power in the structure of the public authorities, which is organically linked with the constantly increasing of the scope of judicial power (especially constitutional courts), that leads to the state when in principle every important policy decision is under judicial control." 10

On the other side, in democratic society the influence of politics on law is clear and expected as the politics has influence on the judicial power. ${ }^{11}$ The same shall apply to the Constitutional Court, that is, a specialized expert body, while also as a political body. ${ }^{12}$ Constitutional Court oscillates between law and politics. Constitutional Court without any doubts is closer to politics than general courts, since in many procedures it decides on the political decisions of the parliament, the government, and the president. The consequences of its decisions have mainly a political character, since the political powers of the state correct their decision according to its opinions and recommendations. ${ }^{13}$

Thus, the links between politics and the constitutional judiciary have been and are much more complicated than they might seem given the superficial blaming of politics. And it is the relationship between politics and the constitutional judiciary that is addressed in this document, in particular in the context of the constitutional judge's selection. An important question arises: what can be done to improve their independence? The answer is based on a set of rules for the selection of judges that are to the minimum extent in contrary to the principle of independency of the constitutional judiciary on the political ground and effective protection of constitutionality or in the ideal case, the rules that are fully compatible with the requirement independency of the constitutional judge. Searching for these rules in the legal regulation from among the states in Europe (whether in post-socialistic

\footnotetext{
${ }^{8}$ Badó, A., Political, merit-based and nepotic elements in the selection of Hungarian judges. A possible way of creating judicial loyalty in East Central Europe," International Journal of the Legal Profession", 2017, Vol. 24, no. 3, p. 2.

${ }^{9}$ Spáč, S., The Illusion of Merit-Based Judicial Selection in Post-Communist Judiciary: Evidence from Slovakia,"Problem of Post-Communism", 2020, p. 6.

${ }^{10}$ Orosz, L., Ustanovovanie sudcov Ústavného súdu Slovenskej republiky a zánik ich funkcie (náčrt aktuálnych problémov), [Appointment of judges of the Constitutional Court of the Slovak Republic and termination of their office (outline of current issues)], "Organizácia súdnej moci v Pol'skej Republike, Českej Republike a Slovenskej Republike", ["Organisation of the judicial power in the Poland, in the Czech Republic and in the Slovak Republic"], 2019, ŠafárikPress, Košice, p.18.

11 Klíma, K., Nezávislost soudni soustavy - současná dilemata a jejich ústavněprávni řešení, [Independence of the judicial system - current dilemmas and their constitutional solutions], "Organizácia súdnej moci v Pol'skej Republike, Českej Republike a Slovenskej Republike", ["Organisation of the judicial power in the Poland, in the Czech Republic and in the Slovak Republic"], 2019, ŠafárikPress, Košice, p. 8.

${ }^{12}$ Drgonec, J., Ústavné právo hmotné, [Substantive constitutional law], 2018, C. H. Beck, Bratislava, 2018 , p. 365.

${ }^{13}$ Giba, M., Ústavné právo, [Constitutional law], 2019, Wolters Kluwer, Bratislava, p. 303.
} 
state, or in states of the traditional democracy), including Slovakia and in other scientific work is the important subject to this document.

The formulation of the scientific hypothesis is that the constitutional regulation of the selection of candidates for constitutional judges in the Slovak Republic so far allowed selection of a majority of constitutional judges by a single political establishment and at the same time the passivity of the parliament in the non-selection of the candidates in time before and after expiration the term of office of previous constitutional judges. The interference with the independence and effective functioning of the constitutional judiciary by the sole leading political representatives still persists due to the lack of political and legal culture in Slovakia. In addition, the "light of hopes" and expectations may be brought by the constitutional reform of the Constitution of the SR conducted by the last constitutional amendment No. 422/2020 Coll., which may bring a brake against the concentration of power in the hands of one political representation as well as functional mechanisms that could strengthen the independence and efficiency of the constitutional judiciary.

The aim of this document is therefore the comparative analyses of the selecting constitutional judges in selected states of the European Union, with special regards to the composition of the Constitutional Court (number of judges), term of office (with possibility of its extension), selection procedure and the quorum required for the election in parliament, as well as the partial replacement of the judges, the analyse of the previous evolution, the current state as well as the perspectives of further development of constitutional regulation of the creation of judges of the Constitutional Court of the Slovak Republic (hereinafter referred to as the "Constitutional Court of the SR "), including the extraordinary actual constitutional judiciary's reform, with related problems arising in application practice, finally, the creation of the ,ideal "model of the selection of constitutional judges that provides the strengthening the independency of constitutional judiciary (especially for judges).

To achieve the aim of this document, it was necessary to use the theoretical research methods. Firstly, to analyse the current legal regulation of selection of constitutional judges in selected states of the European Union and then to analyse the previous, current and further legal regulations in the Slovak Republic. In the context of the findings of comparative research to synthetize the comparative results, which can lead to describing the ,ideal "model that provides the strengthening the independency of the constitutional judiciary (especially for judges). Subsequently, I shall try to deduce a relatively comprehensive de constitutione, resp. de lege ferenda proposals for legal regulation of the selection of constitutional judges in Slovakia to strengthen and improve their independency apart mainly from politicians. Finally, I shall present my considerations and general evaluation about the possible effects of the reforms in the future, with a reasonable objectified distance from their unquestionable political dimension. 


\section{Selecting constitutional judges in selected states of the European Union}

In this context I focus on 18 states of the European Union where the Constitutional Court has place in the system of state jurisdictional bodies as a special court (often outside the ordinary court system, has the power to consider the constitutionality of legal regulations According to this model, the Constitutional Court exercises constitutional review is a competent authority. ${ }^{14}$ They are often called "Kelsenian courts" because they follow the model of the Austrian Constitution of 1920 in whose creation the eminent jurist Hans Kelsen had a prominent role. ${ }^{15}$ In Kelsenian models constitutional review is concentrated in an institution whose members have been politically appointed in a very visible way. From the outset, the Kelsenian model gave prerogative to appoint constitutional judges to political actors especially to the parliament, under the assumption that constitutional review of legislation was a quasi-legislative function. Since constitutional judges are appointed to perform a de facto political function, it is not strange that political criteria underlie in appointments. This in itself can affect the image of neutrality of the court. And the problem is aggravated when, in connection to the system of appointments, political preferences guide judicial decision-making. ${ }^{16}$ Therefore comparative analysis contains certain (mostly political) elements of the selection procedures in various states that are concentrated in the table 1 .

\section{The comparative analysis of selecting constitutional judges} in selected European countries

\begin{tabular}{|c|c|c|c|c|c|c|c|}
\hline & $\begin{array}{c}\text { European } \\
\text { states }\end{array}$ & $\begin{array}{l}\text { Number } \\
\text { of judges }\end{array}$ & $\begin{array}{l}\text { Model of } \\
\text { selection }\end{array}$ & $\begin{array}{l}\text { Quorum } \\
\text { required for } \\
\text { the election of } \\
\text { a judge }\end{array}$ & $\begin{array}{l}\text { Term } \\
\text { of } \\
\text { office } \\
\text { in } \\
\text { years }\end{array}$ & $\begin{array}{c}\text { Extension } \\
\text { of the } \\
\text { term of } \\
\text { office }\end{array}$ & $\begin{array}{c}\text { Partial } \\
\text { Replacement } \\
\text { of the judges }\end{array}$ \\
\hline 1 & Austria & $\begin{array}{c}14+6 \\
\text { substitute } \\
\text { members }\end{array}$ & $\begin{array}{l}\text { Hybrid model: } \\
\text { Appointment by } \\
\text { the Federal } \\
\text { President: } 6 \\
\text { judges }+3 \\
\text { substitute } \\
\text { members } \\
\text { nominated by the } \\
\text { Government, } 6 \\
\text { judges }+3 \\
\text { substitute }\end{array}$ & $\begin{array}{l}\text { the absolute } \\
\text { majority }\end{array}$ & for life & no & no \\
\hline
\end{tabular}

${ }^{14}$ Berestova, I., Yurovska, G., The Constitutional Court in the mechanism of domestic remedies in states with direct access to constitutional justice: Operational and economic Aspects, "Baltic Journal of Economic studies", 2020, Vol. 6, no. 1, p.19.

${ }^{15}$ Castillo-Ortiz P., The dilemmas of constitutional courts anf the case for a new design of Kelsenian institutions, "Law and Philosophy", 2020, Vol. 39, p. 618.

16 Navarrete, R. M., Castillo-Ortiz, P., Constitutional courts and citizens' perceptions of judicial systems in Europe, "Comparative European Politics", 2020, Vol. 18, no. 2, p.134. 


\begin{tabular}{|c|c|c|c|c|c|c|c|}
\hline & $\begin{array}{l}\text { European } \\
\text { states }\end{array}$ & $\begin{array}{l}\text { Number } \\
\text { of judges }\end{array}$ & $\begin{array}{l}\text { Model of } \\
\text { selection }\end{array}$ & $\begin{array}{l}\text { Quorum } \\
\text { required for } \\
\text { the election of } \\
\text { a judge }\end{array}$ & $\begin{array}{l}\text { Term } \\
\text { of } \\
\text { office } \\
\text { in } \\
\text { years }\end{array}$ & $\begin{array}{l}\text { Extension } \\
\text { of the } \\
\text { term of } \\
\text { office }\end{array}$ & $\begin{array}{c}\text { Partial } \\
\text { Replacement } \\
\text { of the judges }\end{array}$ \\
\hline & & & $\begin{array}{l}\text { members partly } \\
\text { nominated by the } \\
\text { National Council } \\
\text { and partly by the } \\
\text { Federal Council. }\end{array}$ & & & & \\
\hline 2 & Belgium & 12 & $\begin{array}{l}\text { Hybrid model: } \\
\text { Nomination by } \\
\text { the Head of the } \\
\text { State after } \\
\text { proposal by the } \\
\text { House of } \\
\text { Representative } \\
\text { and the Senate }\end{array}$ & $\begin{array}{l}\text { the qualified } \\
\text { majority }\end{array}$ & for life & yes & no \\
\hline 3 & Bulgaria & 12 & $\begin{array}{l}\text { Direct } \\
\text { nomination: } 1 / 3 \\
\text { by the } \\
\text { parliament, } 1 / 3 \\
\text { by the President, } \\
1 / 3 \text { chosen of the } \\
\text { justice of the } \\
\text { Supreme Court of } \\
\text { Appeals and the } \\
\text { Supreme } \\
\text { Administrative } \\
\text { Court }\end{array}$ & $\begin{array}{l}\text { the simple } \\
\text { majority }\end{array}$ & 9 & no & $\begin{array}{c}\text { every three } \\
\text { years from each } \\
\text { quota, in a } \\
\text { rotation order } \\
\text { established by } \\
\text { law }\end{array}$ \\
\hline 4 & Croatia & 13 & $\begin{array}{l}\text { Election in } \\
\text { Parliament }\end{array}$ & $\begin{array}{l}\text { the qualified } \\
\text { majority }\end{array}$ & 8 & yes & no \\
\hline 5 & $\begin{array}{c}\text { Czech } \\
\text { Republic }\end{array}$ & 15 & $\begin{array}{l}\text { Hybrid model: } \\
\text { Appointment by } \\
\text { the President of } \\
\text { the Republic with } \\
\text { the consent of the } \\
\text { Senate of the } \\
\text { Parliament }\end{array}$ & $\begin{array}{l}\text { the simple } \\
\text { majority }\end{array}$ & 10 & no & no \\
\hline 6 & France & 9 & $\begin{array}{l}\text { Direct } \\
\text { nomination: } 3 \text { by } \\
\text { the President of } \\
\text { the Republic, } 3 \\
\text { by the President } \\
\text { of the National } \\
\text { Assembly, } 3 \text { by } \\
\text { the President of } \\
\text { the Senate }\end{array}$ & $\begin{array}{l}\text { the qualified } \\
\text { majority }\end{array}$ & 9 & no & $\begin{array}{c}\text { every three } \\
\text { years, one-third } \\
\text { of the } \\
\text { Constitutional } \\
\text { Court }\end{array}$ \\
\hline 7 & Germany & 16 & $\begin{array}{l}\text { Election: } 8 \\
\text { judges in the } \\
\text { Bundestag, } 8 \\
\text { judges in the } \\
\text { Bundesrat }\end{array}$ & $\begin{array}{l}\text { the qualified } \\
\text { majority }\end{array}$ & 12 & no & no \\
\hline
\end{tabular}




\begin{tabular}{|c|c|c|c|c|c|c|c|}
\hline & $\begin{array}{c}\text { European } \\
\text { states }\end{array}$ & $\begin{array}{l}\text { Number } \\
\text { of judges }\end{array}$ & $\begin{array}{l}\text { Model of } \\
\text { selection }\end{array}$ & $\begin{array}{l}\text { Quorum } \\
\text { required for } \\
\text { the election of } \\
\text { a judge }\end{array}$ & $\begin{array}{l}\text { Term } \\
\text { of } \\
\text { office } \\
\text { in } \\
\text { years }\end{array}$ & $\begin{array}{c}\text { Extension } \\
\text { of the } \\
\text { term of } \\
\text { office }\end{array}$ & $\begin{array}{c}\text { Partial } \\
\text { Replacement } \\
\text { of the judges }\end{array}$ \\
\hline 8 & Hungary & 15 & $\begin{array}{l}\text { Election: } \\
\text { Parliament by } \\
\text { proposal of } \\
\text { Nominating } \\
\text { Committee }\end{array}$ & $\begin{array}{l}\text { the qualified } \\
\text { majority }\end{array}$ & 12 & no & no \\
\hline 9 & Italy & 15 & $\begin{array}{l}\text { Direct } \\
\text { nomination: } 1 / 3 \\
\text { by Parliament, } \\
1 / 3 \text { by the } \\
\text { President of the } \\
\text { Republic, } 1 / 3 \text { by } \\
\text { the ordinary and } \\
\text { administrative } \\
\text { Supreme Courts }\end{array}$ & $\begin{array}{l}\text { if voting by } \\
\text { the Parliament } \\
\text { - the qualified } \\
\text { majority, if } \\
\text { voting by } \\
\text { superior } \\
\text { tribunals - the } \\
\text { absolute } \\
\text { majority }\end{array}$ & 9 & no & no \\
\hline 10 & Latvia & 7 & $\begin{array}{l}\text { Hybrid model: } \\
\text { Appointment by } \\
\text { the Seima } \\
\text { (parliament) from } \\
\text { candidates } \\
\text { nominated by } 10 \\
\text { members of } \\
\text { Seima ( } 3 \text { judges), } \\
\text { by the Cabinet of } \\
\text { Ministers ( } 2 \\
\text { judges) by } \\
\text { Plenary of the } \\
\text { Supreme Court ( } 2 \\
\text { judges) }\end{array}$ & $\begin{array}{l}\text { the absolute } \\
\text { majority }\end{array}$ & 10 & yes & no \\
\hline 11 & Lithuania & 9 & $\begin{array}{l}\text { Hybrid model: } \\
\text { Appointment by } \\
\text { the Seimas } \\
\text { (parliament) from } \\
\text { candidates } \\
\text { nominated by the } \\
\text { President of } \\
\text { Republic Seima, } \\
\text { the Speaker of } \\
\text { Seimas and the } \\
\text { President of the } \\
\text { Supreme Court - } \\
\text { each } 3 \text { judges }\end{array}$ & $\begin{array}{l}\text { the simple } \\
\text { majority }\end{array}$ & 9 & yes & $\begin{array}{c}\text { every three } \\
\text { years, one-third } \\
\text { of the } \\
\text { Constitutional } \\
\text { Court }\end{array}$ \\
\hline 12 & Luxembourg & 9 & $\begin{array}{l}\text { The Appointment } \\
\text { by the Grand } \\
\text { Duke: } 4 \text { members } \\
\text { ex offo, } 5 \\
\text { members by } \\
\text { opinion on the } \\
\text { Superior Coeur } \\
\text { and }\end{array}$ & no & for life & no & no \\
\hline
\end{tabular}




\begin{tabular}{|c|c|c|c|c|c|c|c|}
\hline & $\begin{array}{l}\text { European } \\
\text { states }\end{array}$ & $\begin{array}{l}\text { Number } \\
\text { of judges }\end{array}$ & $\begin{array}{l}\text { Model of } \\
\text { selection }\end{array}$ & $\begin{array}{l}\text { Quorum } \\
\text { required for } \\
\text { the election of } \\
\text { a judge }\end{array}$ & $\begin{array}{l}\text { Term } \\
\text { of } \\
\text { office } \\
\text { in } \\
\text { years }\end{array}$ & $\begin{array}{l}\text { Extension } \\
\text { of the } \\
\text { term of } \\
\text { office }\end{array}$ & $\begin{array}{c}\text { Partial } \\
\text { Replacement } \\
\text { of the judges }\end{array}$ \\
\hline \multicolumn{8}{|c|}{$\begin{array}{l}\text { Administrative } \\
\text { Court }\end{array}$} \\
\hline 13 & Poland & 15 & $\begin{array}{l}\text { Elected in the } \\
\text { Sejm }\end{array}$ & $\begin{array}{l}\text { the simple } \\
\text { majority }\end{array}$ & 9 & no & no \\
\hline 14 & Portugal & 13 & $\begin{array}{l}10 \text { judges elected } \\
\text { by the Assembly } \\
\text { of the Republic } \\
\text { and } 3 \text { co-opted } \\
\text { by these ( } 6 \\
\text { judges must be } \\
\text { selected from } \\
\text { among the } \\
\text { judges, others } \\
\text { from among } \\
\text { jurists) }\end{array}$ & $\begin{array}{l}\text { the qualified } \\
\text { majority }\end{array}$ & 9 & no & no \\
\hline 15 & Romania & 9 & $\begin{array}{l}\text { Direct } \\
\text { nomination: } \\
3 \text { by the Chamber } \\
\text { of Deputies, } 3 \text { by } \\
\text { the Senate and } 3 \\
\text { by the President } \\
\text { of Romania }\end{array}$ & $\begin{array}{c}\text { the absolute } \\
\text { majority }\end{array}$ & 9 & no & $\begin{array}{l}\text { every three } \\
\text { years, one-third } \\
\text { of the } \\
\text { Constitutional } \\
\text { Court }\end{array}$ \\
\hline 16 & Slovakia & 13 & $\begin{array}{l}\text { Hybrid model: } \\
\text { Appointment by } \\
\text { the President of } \\
\text { the Slovak } \\
\text { Republic on } \\
\text { proposal of the } \\
\text { National Council } \\
\text { of the SR from } \\
\text { twice the number }\end{array}$ & $\begin{array}{l}\text { combined } \\
\text { majority - } \\
\text { firstly the } \\
\text { qualified } \\
\text { majority, in } \\
\text { case of failure, } \\
\text { the absolute } \\
\text { majority }\end{array}$ & 12 & yes & $\begin{array}{c}\text { interim change } \\
\text { in composition } \\
\text { of the } \\
\text { Constitutional } \\
\text { Court regulated } \\
\text { in transitional } \\
\text { provision of the } \\
\text { Constitution } \\
\text { (art. 154g) }\end{array}$ \\
\hline 17 & Slovenia & 9 & $\begin{array}{l}\text { Hybrid model: } \\
\text { The National } \\
\text { Assembly on the } \\
\text { proposal of the } \\
\text { President of the } \\
\text { Republic }\end{array}$ & $\begin{array}{l}\text { the absolute } \\
\text { majority } \\
\text { (majority of } \\
\text { votes) }\end{array}$ & 9 & yes & no \\
\hline 18 & Spain & 12 & $\begin{array}{l}\text { Hybrid model: } \\
\text { Appointment by } \\
\text { the King: } 4 \text { by } \\
\text { proposal of the } \\
\text { Congress of } \\
\text { Deputies, } 4 \text { by } \\
\text { the Senate*, } 2 \text { by } \\
\text { the Government, } \\
2 \text { by the General } \\
\text { Council of } \\
\text { Judiciary }\end{array}$ & $\begin{array}{l}\text { the qualified } \\
\text { majority }\end{array}$ & 9 & yes & $\begin{array}{l}\text { every three } \\
\text { years, one-third } \\
\text { of the } \\
\text { Constitutional } \\
\text { Court }\end{array}$ \\
\hline
\end{tabular}




\subsection{Selection models}

Within the above given scope, three main models of selecting judges can be distinguished depending on institutions, resp. entities involved in the selection of judges.

First relevant type of selection is the direct nomination model, resp. quota system $^{17}$ (or co-nomination), what presents co-participation of some or all branches of state power in selection procedure by nomination of the same proportion the number of candidates, but without mutual cooperation. The direct nomination applies in 4 from 18 selected states which are Bulgaria ${ }^{18}$ France $^{19}$, Romania ${ }^{20}$, and Italy $^{21}$. By comparison, similar features in this system of selection are for example: equal number of judges (9), the same length the term of office (9 years), and partial replacement of the judges every three years (except Italy). Very similar selection procedure of judges is in France and in Romania, where two thirds of judges are appointed by the both chambers of the parliament and one third of judges by the President of the state. However, the appointment of candidates by president in France may by blocked by the three-fifth majority of both parliamentary chamber's committees. Other similar features can be seen in the regulation of Bulgaria and Italy, where third judges are appointed by the Presidents of the states, other third by the parliaments and the last third of judges are chosen by the relevant representatives of judicial power. These regulations include all of the state branches in selection procedure and creates a presumption of the real individual independence of the judges of constitutional courts.

The second mentioned selection procedure include the elective, resp. parliamentary model in which center is the parliament that elects the judges. The various ways of selection as follows:

- election of constitutional judges solely by the parliament $\left(\right.$ Croatia $^{22}$, Hungary ${ }^{23}$ and Germany by the Bundestag and by the Bundesrat $)^{24}$,

- election of constitutional judges by the parliament (Portugal ${ }^{25}$ and Poland $\left.{ }^{26}\right)$, while taking the oath to the hands of the President of the

${ }^{17}$ Kantorowicz, J., Garoupa, N., An empirical analysis of constitutional review voting in the polish constitutional tribunal, 2003-2014, "Constitutional Political Economy", 2016, Vol. 27, no. 1, p. 71. ${ }^{18}$ Constitution of the Republic of Bulgaria, Art. 147, $\$ 1, \S 2$.

19 Council Organisation, „Constitutional Council”, accessed March 1, 2021, https://www.conseilconstitutionnel.fr/en/council-organisation

${ }^{20}$ Statutes of the Judges of the Constitutional Court," The Constitutional Court of Romania", accessed March 1, 2021, https://www.ccr.ro/en/general-presentation/statute-of-the-judges-of-theconstitutional-court/

${ }^{21}$ The Constitution of the Italian Republic, Art. 135.

22 The Constitution of the Republic of Croatia, Art. 122.

${ }^{23}$ The Act CLI of 2011 on the Constitutional Court in Hungary, Art. 3.

${ }^{24}$ Structure - Justice, "The Federal Constitutional Court in Germany", accessed March 2, 2021, https://www.bundesverfassungs gericht.de/EN/Das-Gericht/Organisation/organisation_node.html.

${ }^{25}$ Law of the Constitutional Court Law no, 28/82, of 15 November, Art. 12.

${ }^{26}$ The Constitution of the Republic in Poland, Art. 194. The Act of 30 November 2016 on the Status of the Judges of the Constitutional Tribunal, Art. 2, 3, 4. 
states, who do not participate in the procedure selection, their role has solely protocol character. ${ }^{27}$

The third and the most applied is the hybrid model which represents the mix of the elective and direct nomination. In other words, the model is based on the requirement to reach a consensus of two (or more) constitutional bodies, mostly the parliament and the head of state. It is possible to outline two main line, according to the fact, which constitutional body has the last word on selecting the judges of the Constitutional Court, as well as other various two line:

- The first line is characterized by the last words of the Parliament in selection judges, either by nominations given either (i) by the President of the Republic to the parliament (Slovenia ${ }^{28}$, the Czech Republic ${ }^{29}$ ) or (ii) by broader scope of constitutional entities, including the Government, certain number of parliamentary deputies and the Plenary of the Supreme Court $\left(\right.$ Latvia $\left.^{30}\right)$ or (iii) the Speaker of the Parliament and President of the Supreme Court (Lithuania ${ }^{31}$ ).

- The second line is characterized by the last word of the Head of state (the Monarch or the President of the Republic) in selection judges, either by nominations given (i) by the Parliament (Slovakia), (ii) by the Government and partly by two chambers of the Parliament (the National and the Federal Council in Austria $^{32}$ ).

- The third line is characterized by the inclusion of elective element model into hybrid model (proposal of two chambers of the Parliament to the King in Belgium $^{33}$ ) and direct nomination model into hybrid model (proposal of two chambers of the Parliament, by the Government and by the General Council of the Judiciary to the King in Spain $^{34}$ ), while the Head of state, resp. the Monarch appoints the judges, but without real possibility to refuse the submitted nomination.

- Special category is represented by the appointment of judges by the Grand Duke following the opinion on the Superior Court and the Administrative Court - Luxembourg. ${ }^{35}$

${ }^{27}$ Blašková, B., Vol’ba sudcov/kandidátov na sudcov ústavných súd v národných parlamentoch, [Selecting judges/candidates for judges in national parliaments], "Kancelária Národnej rady Slovenskej republiky", accessed 3 March, 2021 https://www.nrsr.sk/web/ Dynamic/ DocumentPreview.aspx?DocID=458417.

${ }^{28}$ The Constitution of the Republic of Slovenia, Art. 163, Art. 165. Constitutional Court Act, No. 64/07, Art. 13, Art. 14

${ }^{29}$ Constitution of the Czech Republic, Art. 84.

${ }^{30}$ Justices, "Constitutional Court of the Republic of Latvia“, accessed March 3, 2021, https://www. satv.tiesa.gov.lv/en/ structure/justices-of-the-constitutional-court/

${ }^{31}$ Constitution of the Republic of Lithuania, Art. 103. The Law on the Constitutional Court of 1993, No. 6-120, Art. 4.

32 Brochure: The Austrian Constitutional Court, "Verfassungsgerichtshof", accessed March 4, 2021, https://www.vfgh.gv.at/ downloads/VfGH Broschuere eng barrierefrei Final.pdf

${ }^{33}$ Special Act of 6 January 1989 on the Constitutional Court (Belgium), Art. 31 - 34.

${ }^{34}$ Organic Law 2/1979 on the Constitutional Court, of 3 October 1979 (Spain), Art. 16 - 18.

${ }^{35}$ Law of July 27, 1997, on the organization of the Constitutional Court (Luxembourg), Art. 3-5. 


\subsection{Quorum required for the election of a constitutional judge}

As it is clear that in almost every country, the selection of judges is concentrated in parliament with lower or bigger degree of its involvement. Now, in this part of document, it is necessary to particularly look what quorum is required in each parliament to elect judges / candidates for judges of the Constitutional Court. In relation to the quorum required for the election of a judge / candidate for a judge of the Constitutional Court, in most countries a higher number of votes of deputies prevails than a simple majority. Most frequently applied the qualified majority either two thirds of the present members or three-fifth of the present members of the Parliament in eight countries (Belgium, Croatia, France, Hungary, Germany, Italy, Spain, Slovakia, Portugal), further follows the absolute majority, or in other words majority of votes in four countries (Austria, Latvia, Romania, and Slovenia) and finally the simple majority, resp. majority of more than one-half of present deputies in four countries (Bulgaria, the Czech Republic, Lithuania, Poland).

In this context I focus on special provisions concerning the decreasing quorum, if the selection of judges in first ballot fails, for example the parliamentary selection in Italy contains the guarantee against the malfunction of the selective procedure in parliament when the qualified majority decreases from two-thirds majority votes in first three ballots to three-fifths in all subsequent ballots. ${ }^{36}$ Similarly, in case if Slovak parliament fails to select candidates for judges in first ballot, the qualified majority decreases to absolute majority in following ballot if voting.

\subsection{Other criteria for the independence and effectiveness of the Constitutional Court in ensuring continuity in the exchange of judges}

Number of judges varies from state to state. The assessment of the adequate number is quite complicated issue. It has been tackled by various justice systems in different ways. For example, the numbers of judges to be allocated in each court can be calculated based on historical data of incoming, resolved and pending cases, backlogs, and population to be served. ${ }^{37}$

In examined states are constitutional judges appointed either for life until retirement age (in Austria and Belgium until reaching the 70 years, in Luxemburg without the age census) or for certain term of office without the re-appointment. Length of the term of office is determined differently; the most commonly occurring the length of the term of office of 9 years (in 9 states such as Bulgaria, France, Lithuania, Poland, Portugal, Romania, Slovenia, Spain, Italy), hereinafter of

${ }^{36}$ Booklet on The Italian Constitutional Court and its functions, „Corte Constituzionale“, accessed March 12, 2021, https://www.cortecostituzionale.it/documenti/download/pdf/ The Italian_Constitutional_Court.pdf

${ }^{37}$ Fabri, F., Comparing the number of judges and court staff across European countries, "International Journal of the Legal Profession”, 2019, Vol. 26, no. 1, p. 5. 
12 years (in 3 states such as Hungary, Germany, Slovakia), exceptionally 10 years (in 2 states The Czech Republic, Latvia) and of 8 years (Croatia).

The extension of the term of office is valid in 7 states (Belgium, Croatia, Lithuania, Latvia, Slovakia, Slovenia, Spain) which makes it possible to bridge the necessary time in the event that judges are not selected in time. With the extension of the term of office, the legislation of the states is approaching caution, in most cases the necessary period is set, such as 6 months, until a new successor is appointed to office. With connection of the expiration of the term of office, many states regulate the terms and procedures, that precede the selection of the new judges, for example, in Bulgaria three months before expiration of the term, the Chairman of the Constitutional Court propose the relevant entities to appoint the new judges, or in Hungary, the term is set as 90 day before prior to the expiry of the predecessor's term of office.

In some state's rotation or partial replacement of judges occurs (Bulgaria, France, Lithuania, Romania, Slovakia, Spain) mostly connected with direct model of selection. In Austria, in addition to full judges, 6 alternates are elected, who start if the judge is unable to exercise his or her case function - e.g., for health reasons or for bias.

\section{Selecting constitutional judges in the Slovak Republic (previous state, current state and perspectives)}

One of the most important institution in democratic state is the Constitutional Court. Its role is to be the last guarantor of justice for citizens, in case that all of the institutions fail. The existence and proper functioning of the Constitutional Court is the proof that the democratic system is able to remedy deficiencies which have been caused by state institutes. The important status of the Constitutional Court in democratic state pre-determines the constitutional status of its judges (including their selection) who significantly affect the shape of the state for the term of 12 years. ${ }^{38}$

\subsection{Constitutional and legal basis of the Constitutional Court of the Slovak Republic}

The Constitutional Court of the SR was established by the Constitution of the Slovak Republic n. 460/1992 Coll. from 1 September 1992 (herein referred to as "Slovak Constitution" or "Constitution of SR") as an independent judicial body to protect constitutionality according to Article 124 of the Constitution of the SR. The Constitutional Court of the SR was constituted and subsequently established on the ground of art. $124-140$ of the Constitution of the SR which has been amended by

${ }^{38}$ Wifling, P., Problémy pri výbere ústavných sudcov na Slovensku a náčrt alternatívich riešenia, [Problems in the selection of constitutional judges in Slovakia and an outline of alternatives for their solution], "Výber ústavných sudcov," ["Selecting constitutional judges"], 2018, VIA IURIS, Bratislava, p. 8. 
20 amendments so far, while the status and existence of the Constitutional Court of the SR has been changed at least by 7 amendments. ${ }^{39}$

The most important amendments in the area of constitutional judiciary can be considered the third constitutional amendment performed by the constitutional act no. 90/2001 Coll. of 23 February 2001 (which changed one-third of the constitution) and the last revision of the Constitution performed by the constitutional act no. 422/2020 Coll. of 9 December 2020, effective of 1 January 2021, altered the rules governing the reform in the field of judiciary. ${ }^{40}$

The selection of the judges of the Constitutional Court of the SR is actually regulated in art. 134 of the Constitution of SR. The constitutional regulation of selecting constitutional judges is accompanied by two other ordinary acts:

- The Act No. 314/2018 Coll. on the Constitutional Court of 24 October 2018 (hereinafter referred to as "the Constitutional Court Act") which complements the regulation on selection judges in exhaustive enumeration of subjects who are entitled to submit the proposals candidates of constitutional to National Council of the Slovak republic ${ }^{41}$ (herein referred as to "NCSR") as well as the content requirements of the proposal on candidates for constitutional judges.

39 Sangretová, M., Právomoci Ústavného súdu Slovenskej republiky po zmene a doplnení Ústavy Slovenskej republiky, [Jurisdiction of the Constitutional Court of the Slovak Republic after the amendment of the Constitution of the Slovak Republic], "Ústavné dni, 25. výročie Ústavy Slovenskej republiky - VI. ústavné dni“", ["Constitutional day, 25th anniversary of the Constitution of the Slovak Republic - VI. constitutional days"], 2018, UPJŠ, Košice, p. 180.

${ }^{40}$ From the point of content definition, the latest constitutional amendment and the last revision of the Constitution performed by the constitutional act no. 422/2020 Coll. of 9 December 2020 is aimed at: -Establishment of the Highest Administrative Court; - Reform of the composition and the scope of the Judicial Council, including the review of the judges' financial circumstances and judge's eligibility and professionalising of function of Vice-president of the Judicial Council; - Reform of the legal status of the judges of general judges, concerning new regulation of the substantive immunity, annulment of the procedural immunity (annulment of the requirement to give consent by constitutional court for taking the judge into custody), the regulation of the judge's transfer by changes of judicial system in general courts, as well as the establishment of the age census for termination of the function (67 years); - Reform of powers, composition of the Constitutional Court, selection constitutional judges, including precising the requirements for candidates, extension of their term of office, establishing the age census for termination of the function. Another point worthy of mention are the political circumstances that led to adopting the new constitutional amendments, such as political disputes with political deadlock in connection with the selection candidates for constitutional judge in 2019, what caused long-term vacancy of the court. Other considerably disturbing judicial crisis, which justifies the reform, relates to the most extensive corruption on the courts, which have been just revealed. In March 2020, Slovakia's National Criminal Agency arrested 13 high-profile judges, including a former deputy minister of justice, in an operation called "Storm". Charges of corruption, interference with the independence of courts and obstruction of justice were brought. The Raid against Corruption in Courts have been continued: other action named „Gale "was carried out at the end of October 2020. Representatives of the judiciary were detained: among them are judges, including judges of the Supreme Court, as well as a well know lawyer.

${ }^{41}$ According to article 15, the proposals on candidates for judges of the Constitutional Court shall submit to NCSR: the deputies of NCSR, the Government of the SR, the President of the Constitutional Court of SR, the President of the Judicial Council of SR, at least five members of Judicial Council of SR, the President of the Supreme Court of the SR, the President of the Supreme Administrative Court in the SR, the General Prosecutor, the Public Defender of Rights, professional organizations of lawyers, scientific institutions active in the field of law. 
- The Act No. 350/1996 Coll. on the Rules of Procedure of the National

Council of the Slovak Republic (hereinafter referred to as "the Rules of Procedure $N C S R$ ") provides the rules on declaration of the election on candidates for constitutional judges, and consultation on proposal in Constitutional and Legal Affairs Committee of the NCSR.

\subsection{The evolution of selection of the constitutional judges in the Slovak Republic}

Understanding the role of an independent judiciary against a backdrop of parliamentary sovereignty is a critical step in identifying the changing character of the constitution and the one way to approach this issue is through the lens of judicial appointments - any discussion of which is contingent upon an underlying conception of law and theory of the judicial role. ${ }^{42}$ The certain indicative frame on selecting the constitutional judges in concrete realities of evolution of the constitutional system in the Slovak Republic for the period of 1992-2021 may be provided by certain elements of the selection procedures that are concentrated in the table 2 . In this context it is possible to distinguish three periods of selection its judges in the history of the Constitutional Court of the SR:

- the first period from 1993 - 2001 as it can be characterized as the establishment of the Constitutional Court of SR and first years of its existence in the new post-socialistic republic,

- the second period from 2001-2021 is characterized by strengthening of the position of the Constitutional Court of the SR, mainly by extension of its powers and by increasing the number of judges,

- the third period from 2021 starts with the crucial constitutional reform of judiciary, including constitutional judiciary.

The evolution of the selection of the constitutional judges

Table 2

\begin{tabular}{|lccc|}
\hline $\begin{array}{c}\text { The Slovak } \\
\text { Republic } \\
\text { Period }\end{array}$ & $\mathbf{1}$ & $\mathbf{2}$ & $\mathbf{3}$ \\
\hline $\begin{array}{l}\text { Number of judges } \\
\text { Term of office }\end{array}$ & 10 & $\mathbf{2 0 0 1 - 2 0 2 1}$ & $\mathbf{2 0 2 1 -}$ \\
\hline Reappointment & 7 years & 12 years & 13 years \\
\hline $\begin{array}{l}\text { Extension of the } \\
\text { term of office }\end{array}$ & yes & no & no \\
\hline
\end{tabular}

${ }^{42}$ Delaney, E., Searching for constitutional meaning in institutional design: The debate over judicial appointments in the United Kingdom, "Internationa Journal of Constitutional Law", 2016, Vol. 14, No. 3, p. 753. 


\begin{tabular}{|c|c|c|c|}
\hline $\begin{array}{l}\text { The Slovak } \\
\text { Republic }\end{array}$ & 1 & 2 & 3 \\
\hline Period & 1993-2001 & 2001-2021 & 2021- \\
\hline $\begin{array}{l}\text { The time limit for } \\
\text { selection }\end{array}$ & $\begin{array}{l}\text { obligation for } \\
\text { parliament to } \\
\text { submit the } \\
\text { proposal of the } \\
\text { candidates to the } \\
\text { president of the } \\
\text { SR no later than } 3 \\
\text { months before the } \\
\text { expiry of term of } \\
\text { office }\end{array}$ & $\begin{array}{l}\text { obligation for } \\
\text { parliament to } \\
\text { submit the } \\
\text { proposal of the } \\
\text { candidates to } \\
\text { the president of } \\
\text { the SR within a } \\
\text { reasonable time }\end{array}$ & no \\
\hline Selection & $\begin{array}{l}\text { appointment by } \\
\text { the President of } \\
\text { the Slovak } \\
\text { Republic on } \\
\text { proposal of the } \\
\text { National Council } \\
\text { of the SR from } \\
\text { twice the number }\end{array}$ & $\begin{array}{l}\text { appointment by } \\
\text { the President of } \\
\text { the Slovak } \\
\text { Republic on } \\
\text { proposal of the } \\
\text { National } \\
\text { Council of the } \\
\text { SR from twice } \\
\text { the number }\end{array}$ & $\begin{array}{l}\text { appointment by the } \\
\text { President of the Slovak } \\
\text { Republic on proposal of } \\
\text { the National Council of } \\
\text { the SR from twice the } \\
\text { number. Appointment } \\
\text { solely by the President of } \\
\text { the SR from among } \\
\text { elected candidates, if the } \\
\text { Parliament does not elect } \\
\text { the necessary number of } \\
\text { candidates until } 2 \text { months } \\
\text { from expiry of term of } \\
\text { office or until } 6 \text { months } \\
\text { from termination of the } \\
\text { office of previous } \\
\text { constitutional judges. }\end{array}$ \\
\hline $\begin{array}{l}\text { Partial } \\
\text { Replacement of the } \\
\text { judges }\end{array}$ & no & no & $\begin{array}{l}\text { interim change in } \\
\text { composition of the } \\
\text { Constitutional Court } \\
\text { regulated in transitional } \\
\text { provision of the } \\
\text { Constitution (art. } 154 \mathrm{~g} \text { ) }\end{array}$ \\
\hline $\begin{array}{l}\text { Majority in } \\
\text { parliament }\end{array}$ & simple majority & simple majority & $\begin{array}{c}\text { at least third-fifth } \\
\text { majority, if not achieved, } \\
\text { in new election at least } \\
\text { an absolute majority }\end{array}$ \\
\hline
\end{tabular}


On the ground of the data concerning the evolution and the current state of selecting judges in Slovakia (in above mentioned table no. 2), it is possible to draw certain generalizations to name the major problematic areas:

a) Changes supporting the independence of judges. The length of the term of office of judges can undoubtedly be considered as one of the most important guarantees of judicial independence, as their mandate is not subject to renewal by any institution. ${ }^{43}$ In contrary to that hypothesis, the original constitutional regulation allowed the re-appointment after seven years of performance of the office. Such a provision was not sufficient for judicial independence and allowed the political motivation not to submit a proposal to the relevant authorities for reelection. However, the original regulation relating to the length of term of office was firstly changed in 2001 from 7 to 12 years with the impossibility of reappointment. The second change was performed by the last constitutional amendment in 2020 by establishing the age census for termination of office of constitutional judge that is 72 years. The individual independency of judges and certainty is established by explicit and precise, unambiguous legal regulation. Therefore, I consider the increase of the term of office, the impossibility of reappointment and age census or termination of office as an appropriate degree of legal certainty about the irrevocability of the judge.

b) Changes aimed at strengthening the efficiency of the Constitutional Court. Change in number of judges from 10 to 13 was performed due to reinforcement of the status and due to extension of the powers for Constitutional Court of the SR after the massive constitutional changes performed by the constitutional act no. 90/2001 of 23 February 2001.

c) Brakes against the passivity of parliament in the election of candidates for judges of the Constitutional Court. The changes in this area were more than necessary; the first serious mistake of the original legislation was the lack of guarantee in the event of delays in the process of selecting new judges. Such guarantee could be the provision that, at the end of his term of office, a constitutional judge shall have extended office until a new judge is appointed. That provision could preserve the functionality and workability of the Constitutional Court after the expiry of the term of office. On the other side, in the original legislation was the deadline for NCSR to submit the proposals of the candidates for judges to the President of SR no later than 3 months before the expiry of term office. ${ }^{44}$ As the step back we may consider the discharging the provision concerning deadline for parliamentary selection of candidates for judges in $2002 .{ }^{45}$ The lack of guarantee regarding the lack of extension of the term of office and the lack of the deadline for parliament to elect the candidates created space for malfunction of the functioning of the Constitutional Court by non-election of necessary (double) number of candidates for judges for almost 20 years. The requested changes have finally been made in two directions;

${ }^{43}$ Giba, M., Ústavné právo, [Constitutional law], 2019, Wolters Kluwer, Bratislava, p. 295.

${ }^{44}$ Art. 11 par. 2 Act No. 38/1993 Coll. On organization of the Constitutional Court, on the status of judges and on proceedings before Constitutional Court.

45 This change was performed by the Act. No. 124/2002 Coll, which amended the Act. No. 38/1993 Coll. 
the first, very importantly the introduction of the extension of the term office until the taking oath by new constitutional judge (art. 134/3). The second considerably crucial break again passivity of parliament is the exclusion the NCSR from the procedure of selection the judges, in the event of failure to elect the necessary (double) number of candidates for the President of SR. The aim of this change is to prevent the political deadlock by introducing an anti-deadlock mechanism, which represents the selection of judges exclusively by the president (art. 134/3).

d) Brakes against concentrations of power in the hands of one political representation in the election of candidates for judges of the Constitutional Court. As stated by the Venice Commission in its opinion of 2016: "A ruling party not be in a position to have all judges appointed to its liking". ${ }^{46}$ Since the Constitutional Court was established, in parliamentary selection of candidates for judges was sufficient a simple majority of the members of the parliament present, what created conditions for complete exclusion of the opposition from the selection procedure. After the years of discussions about the need to increase the majority in parliamentary selection, the last amendment of the Constitution established the three-fifth majority of all members of parliament (herein after "constitutional" or "qualified majority"). The aim of the provision is to achieve the broad consensus among all spectrum of members of parliament, including parliamentary opposition. If the problem arises from the unwillingness to the mutual agreement between coalition and opposition (due to lack of the political culture in Slovakia), this can be overcome through the above mentioned new anti-deadlock mechanism regulated in art. 134/3 of Slovak Constitution. However, such a provision may bring, without any doubt, potential benefit for the increasing the consensus of the different political representation and for the improvement legitimacy of the Constitutional Court.

e) Strengthening the principle of the irremovability of judges. The constitutional reform includes other change- small in scope but large in meaning when establishing general retirement age on 72 years. The retirement age census is in accordance with the principle of irremovability of judges; under the European standards on the independence of the judiciary and rule of law notes as follows: judges, whether appointed or elected, shall have tenure until a mandatory retirement age or the expiry of the term of office. ${ }^{47}$

\section{The comparative results and conclusions}

Numbers of the author warn of the threat of strong political context for the election of constitutional court judges to the independence of the constitutional judiciary. According to Rosa M. Navarrete, Pablo Castillo-Ortiz, "politicization of an institution like the Constitutional Court suggests that the most important judicial-

${ }^{46}$ Venice Commission, Opinion on the Amendment to the Act of 25. June of the Constitutional Tribunal of Poland, adopted as its 106 th plenary session on 11-12 March 2016, "Council in Europe", accessed March 14, 2021, https://www.venice.coe.int/webforms/ documents/?pdf=CDL-AD(2016)001-e.

${ }^{47}$ Aung, N. G., Principle of irremovability of judges: Judicial independence in Hungary, "Journal of Education Culture and Society“", 2019, Vol. 10, No. 2, p. 297. 
type of body in a country does not decide independently from political pressures." 48 Alessandro Melcarne states, that, "if appointments to the Constitutional Court are enhanced by such political support, in the perspective of future careers, judges are particularly incentivized to keep a strong bond with their political "sponsor" during their mandate. An opportunity in this sense can be found in the event of the law under scrutiny by the Court being passed by the same political coalition that appointed the judge". ${ }^{49}$ Arjana Llano points to the universally known fact that "the process of judge's appointment by their political views without considering their integrity, professional skills and proper qualifications and by excluding the judiciary form of the appointment process, shall be considered as a failure to meet the independence criteria. " 50

Apparently nowhere in the world it has been possible to create an optimal model for the creation of judges of the Constitutional Court. On the contrary, each of the currently applied models of judges' creation has its advantages, but also shortcomings, which are fully manifested especially when the process of appointing judges takes place in a tense socio-political atmosphere and in conditions of deficit of political and legal culture. ${ }^{51}$

The manner in which judges are appointed is undoubtedly one of the factors affecting the independence of the judiciary. From this viewpoint, anchored in the ideal of clearly separated powers, the best method for selecting constitutional judges should be able to a) guarantee or maximize political independence, and b) to identify expertise. ${ }^{52}$ Such a serious personnel decision of the state shall lay in these pillars (according to some constitutional experts and opinions of European Commission for democracy through $\left.l a w^{53}\right)$ :

- Selection of the judges shall be the result of agreement or compromise between several branches of power such as legislative, executive and judicial power. ${ }^{54}$ If one of the branches of state power or one of the constitutional bodies

48 Navarrete, R. M., Castillo-Ortiz, P., Constitutional courts and citizens' perceptions of judicial systems in Europe, "Comparative European Politics", 2020, Vol. 18, no. 2, p.135.

${ }^{49}$ Melcarne, A., Careerism and judicial behavior, "European Journal of Law and economics“, 2017, Vol. 44, no. 2, p. 251.

${ }^{50}$ Llano, A., Independence of judiciary, "Juridical Tribune - Tribuna Juridica", December 2013, Vol. 3, issue 2, p. 111.

${ }^{51}$ Orosz, L., Ustanovovanie sudcov Ústavného súdu Slovenskej republiky a zánik ich funkcie (náčrt aktuálnych problémov), [Appointment of judges of the Constitutional Court of the Slovak Republic and termination of their office (outline of current issues)]," Organizácia súdnej moci v Pol'skej Republike, Českej Republike a Slovenskej Republike", ["Organisation of judicial power in the Poland, in the Czech Republic and in the Slovak Republic"], 2019, ŠafárikPress, Košice, p. 22.

${ }^{52}$ Vandamme, P. É., Hutt, D. B., Selecting Constitutional Judges Randomly," Swiss political Science Review, 2021, 3 p.

${ }^{53}$ Compilation of Venice Commission opinions, reports and studies on constitutional justice, "Venice Commission“, accessed March 15, 2021, https://www.venice.coe.int/webforms/ documents/?pdf=CDL-PI(2020)004-e

${ }^{54}$ Domin, M., Trellová, L., Priama vol'ba sudcov ústavného súdu? Legitimita vs. Nezávislost', [Direct election of judges of the Constitutional Court? Legitimacy vs. Independence], "Independence of the Constitutional Court of the Slovak Republic: Responsibility of the constitutional legislator and the 
should have a dominant share in the selection of judges, independence cannot be said at all. They should not be biased in favour of one party, should not have personal interests at stake in the case and should not have affective ties with any of the parties. ${ }^{55}$

- The longer the judge's term of office, the more positive it has on his independence. ${ }^{56}$ Other reforms to strengthen judicial independence could include the prohibition of the renewability of judges or granting of life tenure to them. ${ }^{57}$

- The larger the majority in parliament in the election of constitutional judges, the better. Therefore, if we are looking for a mechanism with real power relations, but also guarantee, then the election in parliament with the requirement of a constitutional majority is a better security than tinsel and ornamental adjustments. ${ }^{58}$ Even the Venice Commission, in order to ensure democratic legitimacy but avoid politicization, when lay members are appointed by parliament, they should be voted with a qualified majority in order to ensure that a broad agreement is found, with the majority seeking a compromise with the minority. Qualified majorities strengthen the position of the parliamentary minority. ${ }^{59}$

The question is, what way of appointing judges of the Constitutional Court seems to be the most appropriate? I have no ambition to formulate a clear answer to this question. I was only able to get closer to the answer, especially by applying the comparative method, as the issue of models for the selection of judges of Constitutional Court undoubtedly has a significant overlap in international terms, specifically in EU countries.

In this part of document, I will try to outline the suitable model with the least possible political influence in accordance with the comparative knowledge:

- It can be concluded in view of the independency of the constitutional judiciary and minimizing political influence on the selection of judges, the most favorable legislation can be considered those legal regulations that allow a

actors involved in the selection of constitutional judges“, 2019, Univerzita Komenského, Bratislava, p. 36.

55 Vandamme, P. É., Hutt, D. B., Selecting Constitutional Judges Randomly, "Swiss political Science Review", 2021, 4 p.

${ }^{56}$ Domin, M., Trellová, L., Priama vol'ba sudcov ústavného súdu? Legitimita vs. Nezávislost' [Direct election of judges of the Constitutional Court? Legitimacy vs. Independence,], "Independence of the Constitutional Court of the Slovak Republic: Responsibility of the constitutional legislator and the actors involved in the selection of constitutional judges", 2019, Univerzita Komenského, Bratislava, p. 36.

${ }^{57}$ Castillo-Ortiz P., The dilemmas of constitutional courts anf the case for a new design of Kelsenian institutions, "Law and Philosophy", 2020, Vol. 39, p. 646.

${ }^{58}$ Balog, B., Návrh zmien Ústavy Slovenskej republiky vo veci ustanovovanie sudcov Ústavného súdu Slovenskej republiky - spätná reflexia po krátkej dobe, [Proposal for amendments to the Constitution of the Slovak Republic regarding the appointment of judges of the Constitutional Court of the Slovak Republic - retrospective reflection after a short period of time], "Independence of the Constitutional Court of the Slovak Republic: Responsibility of the constitutional legislator and the actors involved in the selection of constitutional judges”, 2019, Univerzita Komenského, Bratislava, p. 50.

${ }^{59}$ Montenegro, Opinion on the draft law on amendments to the law on the Judicial Council and Judges, adopted by the Venice Commision at its 115th Plenary Session (Venice, 22-23 June 2018), "Venice Commission", accessed March 15, 2021, https://www.venice.coe.int/webforms/documents/? $\mathrm{pdf}=\mathrm{CDL}-\mathrm{AD}(2018) 015$-e. 
compromise to be reached, within the parliamentary selection by cooperation of the parliamentary coalition and opposition and at the same time a broad consensus within several or (ideally) in all branches of state power, including the judicial power. Such as legal regulations are possible to find in Italy and in Spain (although with regards to the established quotas, the parliament appoints the majority of constitutional judges).

- Positive assessment includes the group of the post-communistic states such as Bulgaria and the Baltic countries Latvia and Lithuania, where also the Supreme Courts of those countries participate in selection of constitutional judges, although the quorum required fort the election of a judge in parliament reaches the absolute, resp. simple majority.

- The direct nomination model, resp. quota system in France, Bulgaria, Romania and Italy can be evaluated relatively favorably; the advantage of this model is the elimination of conflicts in the appointment of judges, as each body will elect or appoint its nominees, and without the cooperation of another body.

- Relatively high degree of independence reports also the models of selection where is consensus between two chambers of parliament accompanied by the qualified, resp. absolute majority of votes, for example in Austria, Belgium, France, Germany, Spain. Moreover, most of them require the consensus with or separate appointment by the Head of State.

- Overall satisfactory model for the selection of judges represents the hybrid model, specifically "line president - parliament" in the Czech Republic and Slovenia, where the president (resp. head of state) selects the circle of candidates and subsequently submits to the parliament. In that context if judges are nominated by the president as an impartial element and therefore not nominated by their political parties, it is possible to consider that the president could be more exempted from the current political influences. ${ }^{60}$

- The opposite "line parliament-president" a priori, cannot be assessed negatively, although this model of appointment, without specifying certain antideadlock mechanisms, can cause practical problems in appointing judges, as it shows the example of Slovakia.

- On the other side I would propose some reservations relating to weakness possibly affecting the independency of the judges of Constitutional Court. Such legislation, where only one component of state power is dominant, mostly the parliament, I consider to be the least suitable from the point of view of possible politicization of the selection of judges. What is particularly worrying is that the inadequate level of the quorum required for the parliamentary election of a judge, if it is only the simple majority in Poland. G. Borkowski states that "the current system of election of Constitutional Tribunal was widely criticized, it must be stressed that under the current Constitution of Poland of 1997 judges of the Constitutional Court are elected by the Sejm by a simple majority, which in situation

${ }^{60}$ Wifling, P., Problémy pri výbere ústavných sudcov na Slovensku a náčrt alternatív ich riešenia, [Problems in the selection of constitutional judges in Slovakia and an outline of alternatives for their solution], "Výber ústavných sudcov", ["Selecting constitutional judges"], 2018, VIA IURIS, Bratislava, p. 11. 
where one party has a majority, creates a risk of politicisation of these elections. " 61 J. Kantorowicz and N. Garoupa point to the consequence of this procedure, when "the majority in the Sejm can largely influence the elections of the constitutional judges, and give precedence to the candidates of their preference. "62

However, the parliamentary selection of constitutional judges does not $a$ priori presuppose the negative assessment, but according to the opinion of the Venice commission "the election of constitutional judges by the Parliament with the ordinary majority deserves attention." ${ }^{3}$ However, if the solely parliamentary selection of constitutional judges is accompanied by the higher quorum required for the election that simple majority, ideally the qualified majority, it should give sufficient protection from electing the judges by one parliamentary representative.

The question that after comparative result arises is, how Slovakia's model of selection of constitutional judges stands among others European selection models?

The development of the Slovak constitutional has undergone significant changes since its inception and during its existence, which necessarily concerned its composition and appointment of the judges as well. The legal regulation of the appointment of judges was not optimal, which ultimately led to many problems in practice; the Constitutional Court's appointing mechanisms in Slovakia has been heavily influenced by political actors so far, which led to the political disputes with political deadlock in connection with the selection of candidates for constitutional judge in 2019, what caused long-term vacancy of the court. The threat of politicization of the Constitutional Court still have persisted, as judges appointed by the Parliament or the President of the Republic can (almost) all be identified with specific political affiliation. Even Venice commission criticized the way of appointment of constitutional judges. ${ }^{64}$ The immediate change had to come, performed by new constitutional amendment no. 422/2020 Coll., which we can consider as the trend of objective change, what can be assessed positively, while its address is reflection of constitution on social changes and respecting of dynamic function of the constitution. ${ }^{65}$ The model for appointing judges has been maintained,

${ }^{61}$ Borkowski, G., Sovgyria, O., Current judicial reform in Ukraine and in Poland: Constitutional and European Legal aspect in the context of independent judiciary, "Access to justice in eastern Europe", 2019, Vol. 2, no. 3, p. 8 .

${ }^{62}$ Kantorowicz, J., Garoupa, N., An empirical analysis of constitutional review voting in the polish constitutional tribunal, 2003-2014," Constitutional Political Economy", 2016, Vol. 27, no. 1, p. 71.

${ }^{63}$ Compilation of Venice Commission opinions, reports and studies on constitutional justice, "Council of Europe", accessed 20 March 2021 https:/www.venice.coe.int/webforms/documents/?pdf=CDLPI(2020)004-e

${ }^{64}$ Slovak Republic Opinion on questions relating to the appointment of judges of the Constitutional Court, adopted by the Venice Commission at its 110th Plenary Session (Venice, 10-11 March 2017), "Council of Europe", accessed 20 March 2021 https://www.venice.coe.int/webforms/ documents/?pdf=CDL-AD(2017)001-e

${ }^{65}$ Krunková, A., Nové trendy v novelizáciách Ústavy Slovenskej republiky [New trends in amendments to the Constitution of the Slovak Republic], "Ústavné dni, 25. výročie Ústavy Slovenskej republiky - VI. ústavné dni", ["Constitutional day, 25th anniversary of the Constitution of the Slovak Republic - VI. constitutional days”], 2018, Univerzita Pavla Jozefa Šafárika v Košiciach, p. 98. 
although some other options were considered, for example about the direct model, or so-called Czech model, when president appoints the judges after their consent by the Senate. ${ }^{66}$

On the other hand, the recent model of appointing judges, in which the parliament and the president participate as political components and a priori, cannot be assessed negatively, as the latest constitutional amendment undoubtedly contributed to significantly strengthening the independence and efficiency of the constitutional court. Exceptionally favorable changes can be considered the combination of the qualified majority with the anti-deadlock mechanism, that excludes the parliament from the election process if it does not fulfill its role in electing candidates for judges of the Constitutional Court. Other significant change is the extension of the term of office, in case the new judge is not appointed in time and establishment of the age census for termination of the function.

The requested changes have finally been made, but I don't consider them as sufficient. On the one hand, the changes made by the last revision has brought the introduction of the extension of the term office and renewed selection procedure. On the other hand, the deadline for parliament to elect candidates has not been established. According to my opinion the requirement to elect twice the number candidates is also the reason of the malfunctions of the Constitutional Court. In this time, it seems to be the surplus constitutional provision and I presume that we can find the quality candidates from among fewer candidates.

In my opinion, the changes are capable to positively influence further development, but need to be kept in mind at all times, that even in future, under the conditions of the Slovak Republic, it will not be possible to avoid sovereign politically motivated interference in the process of appointing judges. The means of their more significant reduction must be sought primarily in a more significant increase in the level of political and legal culture and respect for the mission of the Constitutional Court.

\section{Bibliography}

1. Badó A., Political, merit-based and nepotic elements in the selection of Hungarian judges. A possible way of creating judicial loyalty in East Central Europe, "International Journal of the Legal Profession“", 2017, Vol. 24, no. 3, pp. 1-16.

2. Balog B., Návrh zmien Ústavy Slovenskej republiky vo veci ustanovovanie sudcov Ústavného súdu Slovenskej republiky - spätná reflexia po krátkej dobe [Proposal for amendments to the Constitution of the Slovak Republic regarding the appointment of judges of the Constitutional Court of the Slovak Republic - retrospective reflection after a short period of time], "Independence of the Constitutional Court of the Slovak Republic: Responsibility of the constitutional legislator and the actors involved in the selection of constitutional judges“, 2019, Univerzita Komenského, Bratislava, pp. 43-51.

${ }^{66}$ Wifling, P., Problémy pri výbere ústavných sudcov na Slovensku a náčrt alternatív ich riešenia, [Problems in the selection of constitutional judges in Slovakia and an outline of alternatives for their solution], "Výber ústavných sudcov", ["Selecting constitutional judges"] 2018, VIA IURIS, Bratislava, p. 10. 
3. Berestova I., Yurovska, G., The Constitutional Court in the mechanism of domestic remedies in states with direct access to constitutional justice: Operational and economic Aspects, "Baltic Journal of Economic studies“, 2020, Vol. 6, no. 1, pp.18-25.

4. Borkowski G., Sovgyria O., Current judicial reform in Ukraine and in Poland: Constitutional and European Legal aspect in the context of independent judiciary, "Access to justice in eastern Europe“, 2019, Vol. 2, no. 3, pp. 5-35.

5. Brown N. J., Waller J. G., Constitutional courts and political uncertainty: Constitutional ruptures and the rule of judges, "Internatinal Journal of Constitutional Law“, 2016, Vol. 14, no. 4, p. 817-850.

6. Delaney, E., Searching for constitutional meaning in institutional design: The debate over judicial appointments in the United Kingdom,"International Journal of Constitutional Law, 2016, Vol. 14, No. 3, pp. 752-768.

7. Dijk F. V., Vos G., A method for assessment of the independence and accountability of the Judiciary, "International Journal for Court Administration", 2018, Vol. 9, no. 3, pp. 1-21.

8. Domin M., Trellová L., Priama vol'ba sudcov ústavného súdu? Legitimita vs. Nezávislost' [Direct election of judges of the Constitutional Court? Legitimacy vs. Independence,], "Independence of the Constitutional Court of the Slovak Republic: Responsibility of the constitutional legislator and the actors involved in the selection of constitutional judges“, 2019, Univerzita Komenského, Bratislava, pp. 30-42.

9. Drgonec J., Ústavné právo hmotné [Substantive constitutional law], 2018, C. H. Beck, Bratislava, p. 506.

10. Castillo-Ortiz P., The dilemmas of constitutional courts anf the case for a new design of Kelsenian institutions, „Law and Philosophy“, 2020, Vol. 39, pp. 617-655.

11. Fabri M., Comparing the number of judges and court staff across European countries, "International Journal of the Legal Profession“, 2019, Vol. 26, no. 1, pp. 5-19.

12. Fałkowski J., Lewkowicz J., Are Adjudication Panels strategically selected? The case of Constitutional Court in Poland, "International Review of Law and Economics", 2021, Vol. 65, pp. 1-12.

13. Giba M. a kolektív, Ústavné právo, [Constitutional law], 2018, Wolters Kluwer, Bratislava, p. 481.

14. Kantorowicz J., Garoupa N., An empirical analysis of constitutional review voting in the polish constitutional tribunal, 2003-2014, "Constitutional Political Economy“, 2016, Vol. 27, no. 1, p. 66-92.

15. Klíma K., Nezávislost soudní soustavy - současná dilemata a jejich ústavněprávní rešení, [Independence of the judicial system - current dilemmas and their constitutional solutions], "Organizácia súdnej moci v Pol’skej Republike, Českej Republike a Slovenskej Republike“" ["Organisation of the judicial power in the Poland in the Czech Republic and in the Slovak Republic"], 2019, ŠafárikPress, Košice, pp. 7-16.

16. Krunková, A., Nové trendy v novelizáciách Ústavy Slovenskej republiky [New trends in amendments to the Constitution of the Slovak Republic], "Ústavné dni, 25. výročie Ústavy Slovenskej republiky - VI. ústavné dni“ ["Constitutional day, 25th anniversary of the Constitution of the Slovak Republic - VI. constitutional days"], 2018, Univerzita Pavla Jozefa Šafárika v Košiciach, pp. 95-107.

17. Llano A., Independence of judiciary, "Juridical Tribune - Tribuna Juridica“, December 2013, Vol. 3, issue 2, pp. 109-115.

18. Melcarne A., Careerism and judicial behavior, "European Journal of Law and Economics“, 2017. Vol. 44, no. 2, pp. 242-264 
19. Navarrete R. M., Castillo-Ortiz P., Constitutional courts and citizens' perceptions of judicial systems in Europe, "Comparative European Politics“, 2020, Vol. 18, no. 2 (2020): p. 129-150.

20. Orosz L., Ustanovovanie sudcov Ústavného súdu Slovenskej republiky a zánik ich funkcie (náčrt aktuálnych problémov), [Appointment of judges of the Constitutional Court of the Slovak Republic and termination of their office (outline of current issues)], "Organizácia súdnej moci v Pol'skej Republike, Českej Republike a Slovenskej Republike" ["Organisation of the judicial power in the Poland in the Czech Republic and in the Slovak Republic"], 2019, ŠafárikPress, Košice, pp.18-43.

21. Sangretová M., Právomoci Ústavného súdu Slovenskej republiky po zmene a doplnení Ústavy Slovenskej republiky, [Jurisdiction of the Constitutional Court of the Slovak Republic after the amendment of the Constitution of the Slovak Republic], "Ústavné dni, 25. výročie Ústavy Slovenskej republiky - VI. ústavné dni“", ["Constitutional day, 25th anniversary of the Constitution of the Slovak Republic - VI. constitutional days"], 2018, UPJŠ, Košice, pp. 172-190.

22. Spáč S., The Illusion of Merit-Based Judicial Selection in Post-Communist Judiciary: Evidence from Slovakia, "Problem of Post-Communism", 2020, pp. 1-11.

23. Vandamme P. É., Hutt D. B., Selecting Constitutional Judges Randomly, "Swiss political Science Review“, 2021, Vol. 2, pp. 1-21.

24. Wifling P., Problémy pri výbere ústavných sudcov na Slovensku a náčrt alternatívich riešenia, [Problems in the selection of constitutional judges in Slovakia and an outline of alternatives for their solution], "Výber ústavných sudcov" ["Selecting constitutional judges"], 2018, VIA IURIS, Bratislava, pp. 8-13. 